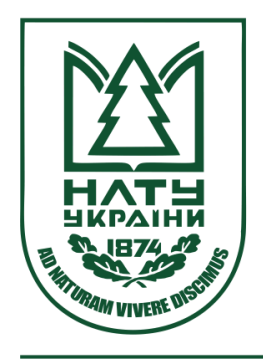

Науковий вісник НЛтУ України Scientific Bulletin of UNFU

https://nv.nltu.edu.ua

https://doi.org/10.36930/40290911

$@ \bowtie$ Correspondence author

Article received 15.10.2019 p.

Article accepted 26.12.2019 p.

L. I. Kopiy

UDK $630 * 644.2$

В. М. Сухович, С. Л. Копій, Ю. Й. Каганяк, Л. І. Копій, о. П. Шикула, М. Л. Копій

Національний лісотехнічний університет Украӥни, м. Львів, Украйна

\title{
СТРУКТУРНИЙ АНАЛІЗ РОЗПОДІЛУ ЗАПАСУ СОСНОВИХ ДЕРЕВОСТАНІВ У ХАРАКТЕРНИХ ДЛЯ РОЗРОБКИ БУРШТИНУ ЛІСОРОСЛИННИХ УМОВАХ НА ТЕРИТОРІЇ ДП "ДУБРОВИЦЬКЕ ЛІСОВЕ ГОСПОДАРСТВО"
}

\begin{abstract}
Територія лісового фонду ДП "Дубровицьке лісове господарство" характеризується комплексним використанням природних ресурсів. Лісові екосистеми є джерелом стиглої деревини. Підприємство відзначається значною різноманітністю лісорослинних умов, що зумовлює потребу в розробленні системи лісогосподарських заходів для вирощування високопродуктивних та екологічно стійких лісових насаджень. Одночасно на території таких об'єктів здійснюють самовільне видобування бурштину. Цей процес у майбутньому сприятиме істотній зміні перебігу нагромадження запасу деревними породами. Здійснено інвентаризацію соснових деревостанів та оцінено структуру деревного запасу у вологому суборі (найпоширеніший тип лісорослинних умов, у межах якого проводять несанкціоноване видобування бурштину) на території державного підприємства "Дубровицьке лісове господарство" для подальшої оцінки втрат деревини на ділянках, що порушені видобутком бурштину. Об'єктом дослідження є чисті та мішані соснові деревостани на непорушених землях. Предметом дослідження $є$ структура запасу зазначеного об'єкту. Детальний аналіз структури деревостану проведено на дванадцяти дослідних ділянках. Запас для кожного елемента лісу розподілено на десять рівновеликих частин. Аналіз розподілу запасу за рівновеликими частинами виявив його істотну мінливість. Виділено сім груп об'єктів. У межах кожної рівновеликої частини підтверджено мінливість частки запасу. Вказано на мінливість розподілу запасу за рівновеликими частинами деревостану.
\end{abstract}

Ключові слова: видобування бурштину; деревостан, запас; рівновелика частина; сосна; показник мінливості.

Вступ. Відомо, що лісові екосистеми є істотним стабілізаційним чинником середовища. Ефективність функціонування лісового насадження і темпи нагромадження деревного запасу значною мірою визначають обсяги комплексного використання лісових ресурсів. Тому відтворення та формування стійких продуктивних лісових насаджень можна віднести до пріоритетних завдань ведення лісового господарства. Реалізація таких завдань може істотно корегуватися виробничою діяльністю, заснованою на використанні інших природних ресурсів, що виявлені на тій самій території. Нерідко доводиться констатувати саме негативні наслідки (винищення деревостанів під час видобування бурштину) користувань такими природними ресурсами (Bogdasarov et al., 1994; Korniienko, 2014; Kurepa, 2007).

На території лісового фонду ДП "Дубровицьке лісове господарство" (Рівненське обласне управління лісового та мисливського господарства) зафіксовано розробку бурштину. Використання цього природного ресурсу відбувається тривалий час (до 20 років). Ірунти таксаційних виділів з сосновими та іншими деревостанами зазнають відчутної деградації із різним ступенем. Ці зміни є логічним продовженням процесу, започаткованого вимиванням мінералу. Порушення базового компоненту лісової екосистеми, яким є грунтовий покрив, активізує структурні зміни під час вирощування деревостанів на порушених ділянках.

Об'єктом дослідження є чисті та мішані соснові деревостани у вологому суборі на території ДП "Дубровицьке лісове господарство", які найчастіше пошкоджуються (переважно знищуються) під час видобування бурштину.

Предметом дослідження є методи і засоюи, які дають змогу визначити структуру запасу зазначеного об'єкта.

Метою дослідження є інвентаризація соснових деревостанів на непорушених ділянках та аналіз структури деревного запасу для оцінки втрат в ідентичних умовах під час видобування бурштину.

\section{Інформація про авторів:}

Сухович Віталій Миколайович, аспірант, кафедра екології. Email: kop.l@i.ua

Копій Сергій Леонідович, канд. с.-г. наук, доцент, кафедра лісівництва. Email: s.kopiy@email.ua

Каганяк Юліан Йосипович, д-р с.-г. наук, професор, кафедри лісової таксації та лісовпорядкування. Email: julij_k@yahoo.ca

Копій Леонід Іванович, д-р с.-г. наук, професор, завідувач кафедри екологіï. Email: kop.l@i.ua

Шикула Олександра Петрівна, канд. філософ. наук, доцент, кафедра філософії та психологіï. Email: kop.l@i.ua

Копій Марія Леонідівна, канд. с.-г. наук, асистент, кафедра екології. Email: marykop16@ukr.net

Цитування за ДСтУ: Сухович В. М., Копій С. Л., Каганяк Ю. Й., Копій Л. І., Шикула О. П., Копій М. Л. Структурний аналіз розподілу запасу соснових деревостанів у характерних для розробки бурштину лісорослинних умовах на території ДП "Дубровицьке лісове господарство". Науковий вісник НЛтУ України. 2019, т. 29, № 9. С. 65-69.

Citation APA: Sukhovych, V. M., Kopiy, S. L., Kahanyak, Yu. Yo., Kopiy, L. I., Shykula, O. P., \& Kopiy, M. L. (2019). Structural analysis of pine forest resource distribution in characteristic foramber extraction conditions on the territory of Dubrovitsia state forestry enterprise. Scientific Bulletin of UNFU, 29(9), 65-69. https://doi.org/10.36930/40290911 
Методика проведення дослідження. За результатами обстеження лісового фонду підприємства підібрано 12 таксаційних виділів із сосновими деревостанами на грунтах, характерних для розробки бурштину. Первинну інформацію про об'єкт отримано за результатами реалізації методики перелікової таксації із візуальним визначенням окремих лісотаксаційних ознак (виду рослини, типу лісу, категорії технічної придатності дерева тощо). Таксаційні показники розраховано за загальноприйнятими формулами, з якими можна ознайомитися в таких літературних джерелах та наших попередніх наукових працях (Ahii et al., 2016; Vorobev, 1953; Honchar et al., 2012; Dzhonson \& Lion, 1980; Kahaniak, 2005a, 2005b; Kopii et al., 2008; Korniienko, 2014).

Лісотаксаційну характеристику соснових деревостанів на пробних площах подано в табл. 1. Встановлено, що стиглі соснові деревостани характеризуються значним коливанням класу бонітету (від III до I ${ }^{\mathrm{a}}$ ) та відносної повноти (від 0,47 до 0,90). Здебільшого це чисті соснові деревостани, або з невеликою домішкою (1-2 одиниці) дуба, берези, граба. Одна ділянка в умовах вологого дубового субору ( $\left.\mathrm{B}_{3}-\mathrm{-}-\mathrm{C}\right)$ характеризується деревостаном, де частка сосни становить 5 одиниць.

Табл. 1. Лісотаксаційна характеристика соснових деревостанів на характерних землях для видобутку бурштину в умовах вологого субору

\begin{tabular}{|c|c|c|c|c|c|c|c|c|c|c|c|c|c|}
\hline Код & Лісництво & Кв. & Вид. & Тип лісу & Порода & $S n n$ & $N$ & $A$ & $D$ & $H$ & $M$ & $C$ & Б \\
\hline \multirow[t]{4}{*}{68} & Бережницьке & 18 & 2.1 & $\mathrm{~B}_{3}-д \mathrm{C}$ & сосна & 1,00 & 374 & 81 & 30,3 & 27,7 & 336 & 8 & $\mathrm{I}^{\mathrm{a}}$ \\
\hline & & & & & дуб & & 195 & & 21,9 & 20,0 & 76 & 2 & \\
\hline & & & & & граб & & 142 & & 13,4 & 16,6 & 16 & + & \\
\hline & & & & & разом & & 711 & & & & 428 & 10 & \\
\hline \multirow[t]{4}{*}{66} & Бережницьке & 18 & 8.2 & $\mathrm{~B}_{3}-д \mathrm{C}$ & сосна & 0,80 & 379 & 85 & 33,8 & 30,5 & 466 & 10 & $\mathrm{I}^{\mathrm{a}}$ \\
\hline & & & & & дуб & & 51 & & 12,6 & 11,3 & 4 & + & \\
\hline & & & & & береза & & 28 & & 10,4 & 11,3 & 1 & + & \\
\hline & & & & & pa3oм & & 458 & & & & 471 & 10 & \\
\hline \multirow[t]{3}{*}{63} & Бережницьке & 7 & 15.1 & $\mathrm{~B}_{3}-д \mathrm{C}$ & сосна & 0,70 & 294 & 86 & 32,2 & 25,6 & 276 & 9 & $\mathrm{I}$ \\
\hline & & & & & дуб & & 129 & & 20,8 & 19,4 & 45 & 1 & \\
\hline & & & & & разом & & 423 & & & & 320 & 10 & \\
\hline \multirow[t]{4}{*}{10} & Трипутнянське & 8 & 53.1 & $\mathrm{~B}_{3}-д \mathrm{C}$ & сосна & 0,70 & 251 & 84 & 33,5 & 23,2 & 232 & 10 & II \\
\hline & & & & & дуб & & 39 & & 15,9 & 15,0 & 6 & + & \\
\hline & & & & & береза & & 57 & & 19,6 & 15,0 & 11 & + & \\
\hline & & & & & разом & & 347 & & & & 249 & 10 & \\
\hline \multirow[t]{4}{*}{7} & Трипутнянське & 7 & 6.1 & $\mathrm{~B}_{3}-д \mathrm{C}$ & сосна & 0,90 & 317 & 81 & 32,5 & 25,6 & 305 & 10 & $\mathrm{I}$ \\
\hline & & & & & дуб & & 34 & & 13,1 & 12,8 & 3 & + & \\
\hline & & & & & береза & & 68 & & 13,3 & 11,5 & 5 & + & \\
\hline & & & & & разом & & 419 & & & & 313 & 10 & \\
\hline \multirow[t]{3}{*}{12} & Трипутнянське & 12 & 11.1 & $\mathrm{~B}_{3}-д \mathrm{C}$ & сосна & 0,80 & 394 & 83 & 25,8 & 23,7 & 225 & 9 & II \\
\hline & & & & & береза & & 25 & & 29,2 & 22,8 & 15 & 1 & \\
\hline & & & & & разом & & 419 & & & & 240 & 10 & \\
\hline \multirow[t]{4}{*}{314} & Літвіцьке & 19 & 19 & $\mathrm{~B}_{3}-г д \mathrm{C}$ & сосна & 0,40 & 143 & 79 & 29,2 & 20,1 & 87 & 5 & III \\
\hline & & & & & дуб & & 215 & & 21,0 & 15,4 & 61 & 4 & \\
\hline & & & & & береза & & 78 & & 24,4 & 16,5 & 24 & 1 & \\
\hline & & & & & разом & & 435 & & & & 173 & 10 & \\
\hline \multirow[t]{3}{*}{321} & Літвіцьке & 3 & 7 & $\mathrm{~B}_{3}-д \mathrm{C}$ & сосна & 0,30 & 507 & 83 & 23,1 & 18,1 & 176 & 9 & III \\
\hline & & & & & береза & & 47 & & 22,1 & 18,0 & 13 & 1 & \\
\hline & & & & & pa3oм & & 553 & & & & 189 & 10 & \\
\hline \multirow[t]{4}{*}{16} & Літвіцьке & 30 & 15.1 & $\mathrm{~B}_{3}-\mathrm{-д}$ & сосна & 0,70 & 176 & 84 & 31,4 & 27,9 & 171 & 9 & I \\
\hline & & & & & дуб & & 130 & & 17,6 & 14,7 & 26 & 1 & \\
\hline & & & & & береза & & 39 & & 18,7 & 15,8 & 7 & + & \\
\hline & & & & & разом & & 344 & & & & 205 & 10 & \\
\hline \multirow[t]{4}{*}{32} & Дубровицьке & 20 & 4.1 & $\mathrm{~B}_{3}-д \mathrm{C}$ & сосна & 0,60 & 438 & 81 & 30,1 & 25,0 & 351 & 10 & $\mathrm{I}$ \\
\hline & & & & & дуб & & 15 & & 13,5 & 12,6 & 2 & + & \\
\hline & & & & & береза & & 98 & & 13,1 & 11,8 & 7 & + & \\
\hline & & & & & разом & & 552 & & & & 360 & 10 & \\
\hline \multirow[t]{4}{*}{608} & Дубровицьке & 20 & 3 & $\mathrm{~B}_{3}-д \mathrm{C}$ & сосна & 1,00 & 338 & 82 & 28,9 & 24,8 & 247 & 10 & $\mathrm{I}$ \\
\hline & & & & & дуб & & 16 & & 14,2 & 15,6 & 2 & + & \\
\hline & & & & & береза & & 72 & & 15,5 & 12,0 & 7 & + & \\
\hline & & & & & разом & & 426 & & & & 257 & 10 & \\
\hline \multirow[t]{4}{*}{333} & Дубровицьке & 21 & 14 & $\mathrm{~B}_{3}-д \mathrm{C}$ & сосна & 0,50 & 436 & 84 & 27,8 & 21,9 & 263 & 10 & II \\
\hline & & & & & дуб & & 16 & & 11,5 & 14,0 & 1 & + & \\
\hline & & & & & береза & & 134 & & 15,7 & 10,6 & 12 & + & \\
\hline & & & & & разом & & 586 & & & & 276 & 10 & \\
\hline
\end{tabular}

Примітки: Snn - площа ділянки, на якій здійснено перелік дерев, га; $N$ - кількість дерев, шт./га; $A$ - середній вік переважаючої деревної породи, років; $D$ - середній діаметр елемента лісу, см; $H$ - середня висота елемента лісу, м; $M$ - запас елемента лісу, м³/га; $C$ - частка елемента лісу в деревостані, одиниць; $P$ - відносна повнота елемента лісу; Б - клас бонітету переважаючої деревної породи.

Структуру запасу деревостану представлено як розподіл цього показника за 10 рівновеликими частинами.

Рівновелику частину встановлюють як 1/10 від загальної кількості дерев. Алгоритм розподілу запасу за 
10 рівновеликими частинами наведено в попередніх наукових працях (Ahii et al., 2016; Vorobev, 1953; Kahaniak, 2006; Kopii et al., 2014). Критерієм розподілу запасу елемента лісу на рівновеликі частини є дециль. Вихідними даними для структуризації запасу за рівновеликими частинами $є$ перелік кількості дерев за ступенями товщини та модель залежності висоти дерева від діаметра стовбура на висоті 1,3 м.

У попередніх роботах проаналізовано залежності між різними лісівничо-таксаційними і структурними показниками в різних лісорослинних умовах та в насадженнях різного складу. Зокрема, відзначено, що розподіл запасу березово-соснових деревостанів за класами бонітету та елементами лісу підтвердив наявність помірного та сильного кореляційного зв'язку між часткою запасу елементарної частини деревостану та потенційною продуктивністю. Для сосни та берези виявлено закономірне зменшення частки запасу за зменшення потенційної продуктивності деревостану в 1-7 елементарних частинах та обернену залежність для 9-10 елементарних частин (Honchar et al., 2012). Встановлено певні особливості розподілу запасу мішаних деревостанів залежно від типу лісорослинних умов та за елементами лісу. Відзначено тенденцію до зміни запасу у виділених децилях залежно від трофності та вологості. Зокрема, зростання запасу у 1-6 децилях зафіксовано у суборових умовах, а в борових ця особливість простежується лише для 2-4 децилей.

Відповідно, використання зазначеної методики дасть змогу проаналізувати вплив різних чинників на особливості формування часток запасу елементарних частин деревостану в характерних для видобування бурштину лісорослинних умовах.

Результати дослідження та їх аналіз. Унаслідок опрацювання первинних даних переліку дерев на пробних площах отримано розподіл запасу за елементами лісу та рівновеликими частинами деревостану. Видобуток бурштину в межах аналізованого підприємства приурочується до характерних лісорослинних умов ( $\mathrm{B}_{3}-$ C). Підсумок структури запасу для соснових деревостанів на пробних площах подано в табл. 2.

За результатами аналізу даних табл. 2 виділено 7 груп об'єктів. Відповідно до проведених досліджень відзначено, що характеристики деревостанів відрізняються за середнім діаметром та іншими показниками, що дало змогу сформувати відповідні групи. Розподіл запасу сосни за рівновеликими частинами деревостану специфічний для кожного об'єкта.

Табл. 2. Розподіл запасу за елементами лісу (сосна звичайна) та рівновеликими частинами для соснових деревостанів

\begin{tabular}{|c|c|c|c|c|c|c|c|c|c|c|}
\hline \multirow{2}{*}{$\begin{array}{c}\text { Код } \\
\text { пробної площі }\end{array}$} & \multicolumn{8}{|c|}{ Частка запасу за рівновеликими частинами деревостану, \% } \\
\hline & 1 & 2 & 3 & 4 & 5 & 6 & 7 & 8 & 9 & 10 \\
\hline 333 & 2 & 4 & 6 & 7 & 8 & 10 & 11 & 13 & 16 & 23 \\
\hline 608 & 2 & 4 & 6 & 7 & 8 & 10 & 11 & 13 & 16 & 22 \\
\hline 16 & 1 & 4 & 5 & 7 & 9 & 10 & 11 & 14 & 17 & 23 \\
\hline 314 & 2 & 3 & 5 & 6 & 8 & 10 & 12 & 15 & 17 & 22 \\
\hline 7 & 1 & 3 & 5 & 6 & 8 & 10 & 12 & 14 & 17 & 22 \\
\hline 66 & 3 & 5 & 6 & 8 & 9 & 10 & 12 & 14 & 15 & 18 \\
\hline 32 & 1 & 4 & 6 & 7 & 9 & 9 & 11 & 12 & 15 & 27 \\
\hline 10 & 1 & 3 & 4 & 6 & 9 & 11 & 13 & 14 & 16 & 22 \\
\hline 12 & 1 & 2 & 3 & 5 & 7 & 9 & 11 & 14 & 19 & 30 \\
\hline 321 & 1 & 2 & 4 & 5 & 6 & 8 & 10 & 13 & 16 & 35 \\
\hline 63 & 2 & 5 & 6 & 8 & 9 & 10 & 12 & 13 & 15 & 20 \\
\hline 68 & 2 & 4 & 6 & 7 & 8 & 10 & 11 & 13 & 16 & 21 \\
\hline
\end{tabular}

Табл. 3. Біометрична характеристика сосни в межах виділених груп об'єктів

\begin{tabular}{|c|c|c|c|c|c|c|c|}
\hline Група & Код ПП & $D_{a}$ & $V a r$ & $d_{\min }$ & $d_{\max }$ & $A_{s}$ & $E_{x}$ \\
\hline 1 & 66 & 33,2 & 19,9 & 16 & 44 & $-0,08$ & $-0,82$ \\
\hline 2 & 63 & 31,4 & 22,3 & 12 & 48 & $-0,42$ & $-0,09$ \\
\hline 3 & 68 & 29,5 & 23,5 & 16 & 44 & 0,12 & $-0,52$ \\
\hline 4 & $10,7,314,16,608,333$ & $26,9 / 31,9$ & $25,0 / 31,2$ & $8 / 12$ & $44 / 52$ & $-0,30 / 0,60$ & $-0,26 /-0,98$ \\
\hline 5 & 32 & 29,3 & 24,5 & 8 & 52 & 0,22 & 0,14 \\
\hline 6 & 12 & 23,9 & 40,5 & 8 & 48 & 0,12 & $-0,79$ \\
\hline 7 & 321 & 21,7 & 35,3 & 8 & 52 & 0,60 & 0,53 \\
\hline
\end{tabular}

Примітки: $D_{a}$ - середній арифметичний діаметр елемента лісу, см; Var - коефіцієнт варіації; $d_{\min }$ та $d_{\max }-$ ліміти; $A_{s}$ асиметрія розподілу діаметрів; $E_{x}$ - ексцес розподілу діаметрів.

Відмінності підтверджуються додатковою біометричною характеристикою, поданою в табл. 3. У групі 4 зосереджені декілька ділянок, деревостани яких є подібними за окремими характеристиками і були об'єднані в одну групу (Strochynskyi \& Kashpor, 2007; Filipovych, 2016).

Додатковий аналіз біометричних показників, поданих в табл. 3, показує істотну зміну величини середнього арифметичного діаметра, показників мінливості (коефіцієнт варіації, ліміти) та форми розподілу діаметрів (асиметрія, ексцес) між групами об'єктів.

Відмінності частки запасу за величиною між групами підтверджено для всіх рівновеликих частин деревос- тану, за винятком 8 та 9. Графічну інтерпретацію тренду частки запасу сосни в межах рівновеликої частини залежно від групи об'єкта проілюстровано на рисунку.

Отже, детермінованість частки запасу у межах рівновеликої частини деревостану залежно від групи об'єктів істотна. Вона змінюється в межах 64-93 \% (коефіцієнт кореляції перевищує 0,8). Враховуючи, що соснові деревостани сформовані в одному типі лісу та належать до однієї групи віку, можна констатувати помітні відмінності в розподілі запасу за рівновеликими частинами (Strochynskyi, Kashpor \& Berezivskyi, 2007; Strochynskyi \& Kashpor, 2007). 

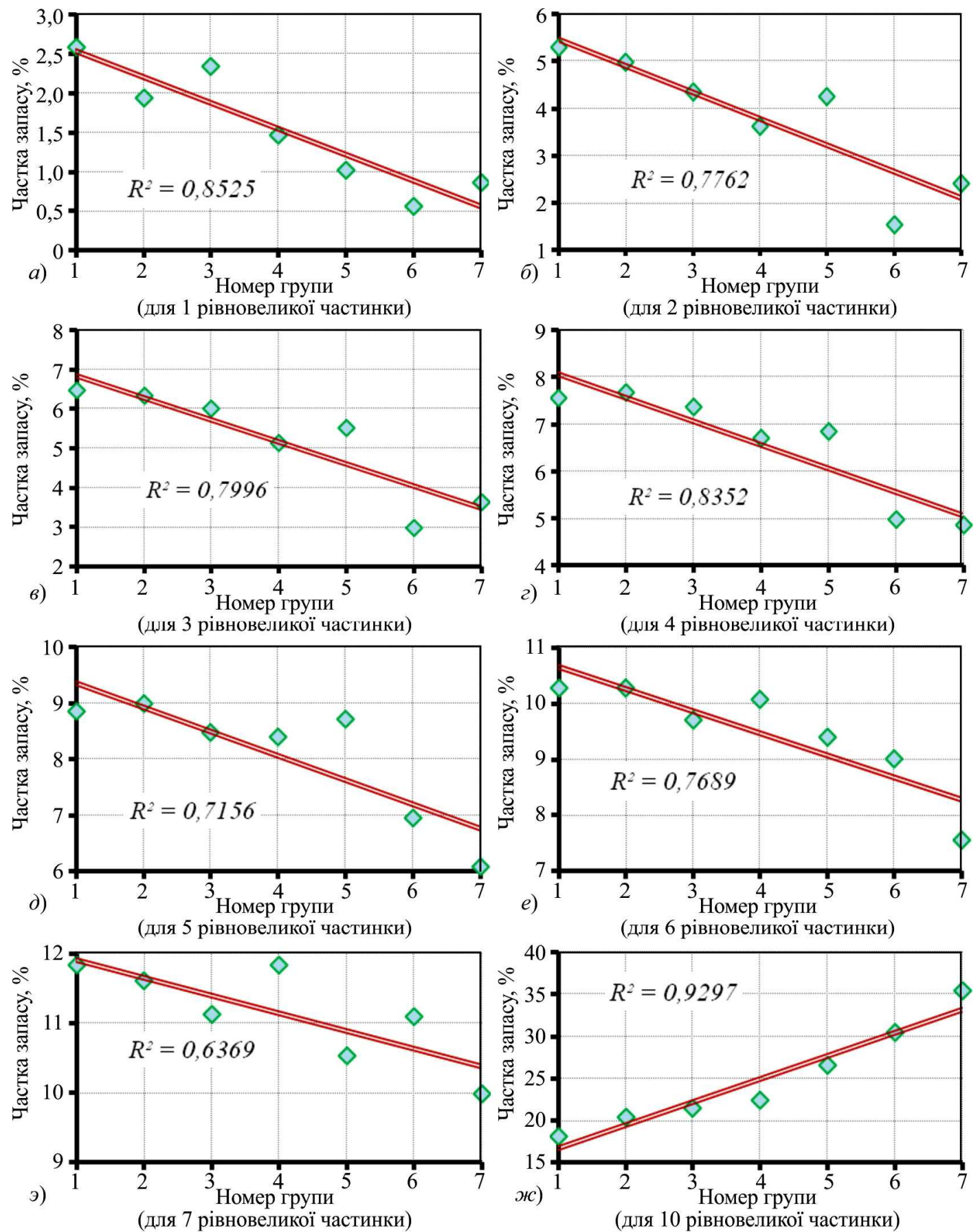

Рисунок. Розподіл запасу сосни в межах рівновеликої частини деревостану для виділених груп об'єктів

Висновки. Коливання індексу класу бонітету (в межах 4 класів), відносної повноти (від низькоповнотних до високоповнотних), а також висока мінливість інших таксаційно-біометричних показників підтверджує структурну різноманітність розподілу запасу в соснових деревостанах вологого субору. Різноманітність структури виражається мінливістю величини частки запасу в межах рівновеликої частини деревостану.

Враховуючи специфіку комплексного використання природних ресурсів на території таких об'єктів, доцільно оцінити можливі втрати деревини та негативний вплив на екологічний стан лісових екосистем, заподіяний видобутком бурштину.

Отримані результати визначення структури запасу та таксаційно-біомеричної характеристики соснових деревостанів, які відзначаються наявністю 7 груп об'єктів, що характеризуються різною специфікою формування деревостанів, свідчать про потреба опрацювання особ- ливої системи лісогосподарських заходів щодо відтворення лісових насаджень в аналізованих умовах, після детального вивчення структури грунтових сумішей на ділянках, порушених розробкою бурштину.

Відтворення деревостанів на порушених видобуванням бурштину ділянках потребує додаткових досліджень щодо способів відтворення, складу деревостанів, технології проведення доглядових рубань та врахування особливостей структури соснових деревостанів в умовах вологого дубового субору.

\section{References}

Ahii, V. O., et al. (2016). Typy rozpodilu zapasu styhlykh hrabovodubovykh derevostaniv Zakarpattia. Scientific Bulletin of UNFU, 26(8), 16-24. https://doi.org/10.15421/40260802

Bogdasarov, A. A., et al. (1994). Perspektivy prakticheskogo ispolzovaniia iskopaemykh smol Belorusskogo Polesia. Mineralogicheskii sbornik Lvovskogo gosudarstvennogo universiteta, 7(1), 71-76. [In Russian]. 
Dzhonson, N., \& Lion, F. (1980). Statistika i planirovanie eksperimenta v nauke i tekhnike. Metody obrabotki dannykh. Moscow: Science, 600 p. [In Russian].

Filipovych, V. Ye. (2016). Metodyka i tekhnolohiia otsinky shkody, nanesenoi Ukrainskii derzhavi vnaslidok nelehalnoho vydobutku burshtynu. Ukrainskyi zhurnal dystantsiinoho zonduvannia Zemli, 11, 15-21. [In Ukrainian].

Honchar, V. M., et al. (2012). Osoblyvosti struktury zapasu berezovososnovykh derevostaniv Zakhidnoho Polissia. (Ser.: Lisivnytstvo ta dekoratyvne sadivnytstvo). (Part 3). Scientific reports of the National University of Bioresources and Natural Resources of Ukraine, 171, 23-29. Kyiv: VTs NUBiP Ukrainy. [In Ukrainian].

Kahaniak, Yu. Y. (2005a). Korotkoterminove prohnozuvannia taksatsiinykh pokaznykiv sosnovoho derevostanu. Scientific Bulletin of UkrSFU, 15(2), 29-35. [In Ukrainian].

Kahaniak, Yu. Y. (2005b). Modyfikatsiia modelei normalnykh zapasiv ta absoliutnykh povnot dlia derevostaniv sosny zvychainoi. Scientific Bulletin of UNFU, 15(4), 49-54. [In Ukrainian].

Kahaniak, Yu. Y. (2006). Prohnoz potentsiinoi produktyvnosti sosnovykh ta bukovykh derevostaniv. Scientific Bulletin of UNFU, 16(6), 39-45. [In Ukrainian].

Kopii, L. I., et al. (2008). Doslidzhennia struktury osnovnykh lisotaksatsiinykh pokaznykiv sosnovykh derevostaniv svizhoho dubovoho suboru zakhidnoho Polissia. Scientific Bulletin of UNFU, 18(11), 115-122. [In Ukrainian].

Kopii, L. I., et al. (2014). Dynamika zapasu elementarnykh chastyn mishanykh derevostaniv Zakhidnoho Polissia. Proceedings of the Forestry Academy of Sciences of Ukraine 12, 140-147. [In Ukrainian].

Korniienko, V. Ya. (2014). Perspektyvy ta suchasnyi stan vydobutku burshtynu v Ukraini. Visnyk Natsionalnoho universytetu vodnoho hospodarstva ta pryrodokorystuvannia, 3(67), 127-133. [In Ukrainian].

Kurepa, S. S. (2007). Ekolohichni naslidky nezakonnoho vydobutku burshtynu v Rivnenskii oblasti. Pryrodno-resursnyi kompleks Zakhidnoho Polissia: istoriia, stan, perspektyvy rozvytku: Conference Proceedings, (pp. 89-90), 25-26 April, 2007. Berezne: Nadsluchanskyi instytut. [In Ukrainian].

Strochynskyi, A. A., \& Kashpor, S. M. (2007). Unifikovana systema bonituvannia lisovykh nasadzhen. Lisotaksatsiini normatyvy. Kyiv: Vydavnychyi tsentr NAU, 8 p. [In Ukrainian].

Strochynskyi, A. A., Kashpor, S. M., \& Berezivskyi, L. M. (2007). Suma ploshch pereriziv ta zapas derevostaniv pry povnoti 1,0. Lisotaksatsiini normatyvy. (2nd ed.). Kyiv: Vydavnychyi tsentr NAU, 19 p. [In Ukrainian].

Vorobev, D. V. (1953). Tipy lesov Evropeiskoi chasti SSSR. Kyiv: Publishing house AN USSR, 452 p. [In Russian].

V. M. Sukhovych, S. L. Kopiy, Yu. Yo. Kahanyak, L. I. Kopiy, O. P. Shykula, M. L. Kopiy

Ukrainian National Forestry University, Lviv, Ukraine

\section{STRUCTURAL ANALYSIS OF PINE FOREST RESOURCE DISTRIBUTION IN CHARACTERISTIC FORAMBER EXTRACTION CONDITIONS ON THE TERRITORY OF DUBROVITSIA STATE FORESTRY ENTERPRISE}

The model of integrated use of natural resources on the territory of the forest fund of the Dubrovytsia State Forestry Enterprise is applied. The basic component of the model is forest planting, which is a source of ripe wood. At the same time, amber is being extracted on the territory of the enterprise for a long time (up to 20 years). This process will help change the course of stockpiling in the future. The purpose of the study is an inventory of pine stands and assessment of the structure of the wood stock in areas that are not affected by amber production, but are characteristic of those that produce amber within the analyzed enterprise. The object of the study is pure and mixed ripe pine stands on undisturbed lands in humid subsoil in the territory of the Dubrovytsia State Forestry Enterprise, where unauthorized amber extraction is mostly often carried out. The subject of the study is the structure of the stock of the specified object. Inventory of the forest fund of the enterprise allowed identifying twelve taxation allocations with soils, which correspond to the structure of stands located on the disturbed extraction of amber. Stands are characterised by a high proportion of silver pine (more than 8 units) here. In some stands, pine is combined with impurities of oak, birch, and hornbeam. The productivity of ripe pine stands is at considerable limits. Stand quality index ranges from III to Ia, and relative completeness - from 0.2 to 0.9 respectively. Structural analysis of pine stands was performed for each element of the forest. The stock is divided into ten equal parts for each element of the forest. The even part represents $1 / 10$ of the total number of trees in the forest element. The theoretical basis for the selection of equal parts of the stand is decile. The algorithm for dividing the stock into equal parts combines the primary information of the list of trees by thickness and elements of the forest with models of the dependence of tree height on the diameter at a height of $1.3 \mathrm{~m}$ and the species number of the tree trunk and diameter at a height of $1.3 \mathrm{~m}$. The distribution of pine stock in equal parts for each sample area was obtained. Variability of pine stock distributions in equal parts is revealed. The analysis of stock distributions was performed on a number of taxation and biometric indicators. The values of the arithmetic mean diameter, coefficient of variation, limits, asymmetry, and excess are analyzed. Their magnitude varies over a large range for mature stands growing in identical forest conditions. The difference in the values of these metrics is given. The objects are divided into seven groups. The significance of the change in the share of the stock within the equal part depending on the group is further evaluated. Within each equal part, the volatility of the stock fraction is quantitatively confirmed. The exception is only 8 and 9 equal parts of the stand. The share of the stock within the equilibrium part of the stand is noticeably dependent on the group of objects. The determination rate ranges within $63-93 \%$ and the correlation coefficient exceeds 0.8 . This indicates a well-defined linear dependence of the share of the equilibrium part of the tree stand on the object group. The results of the assessment of the structure of pine stock and the valuation and biometric characteristics of pine stands indicate the need for correction of forest management measures for the reproduction of indigenous and highly productive stands in areas affected by amber extraction.

Keywords: amber; sample plot; stand; stock; equal parts; pine; indicator; variability. 